\title{
PENGEMBANGAN SISTEM INFORMASI BERBASIS ENTERPRISE RESOURCE PLANNING MODUL PURCHASING (MM-PUR) PADA SAP DENGAN METODE ASAP DI PT UNGGUL JAYA SEJAHTERA
}

\author{
${ }^{1}$ Yani Putri, ${ }^{2}$ Ari Yanuar Ridwan, ${ }^{3}$ R. Wahjoe Witjaksono \\ ${ }^{1,3}$ Program Studi Sistem Informasi, Fakultas Rekayasa Industri, Telkom University \\ ${ }^{2}$ Program Studi Teknik Industri, Fakultas Rekayasa Industri, Telkom University \\ 1yaniputri1995@gmail.com, ${ }^{2}$ ari.yanuar.ridwan@gmail.com, ${ }^{3}$ witjaksonowahjoe@gmail.com
}

\begin{abstract}
Abstrak - PT. Unggul Jaya Sejahtera memproduksi batik printing (batik cetak), perusahaan mulai beroperasi di tahun 1983. Perusahaan yang mendesain, memproduksi, dan memasarkan sendiri produkproduknya. Permasalahan pada PT Unggul yaitu belum terintegrasinya semua aktivitas dalam proses pengadaan dalam suatu sistem sehingga diperlukan untuk pengembangan sebuah sistem yang mengintegrasikan semua aktivitas dalam proses pengadaan. Dalam aktivitas pembelian (purchasing) sering kali terjadi perbedaan pencatatan antara barang yang diminta, barang yang dipesan, dan barang yang diterima. Perusahaan juga kesulitan dalam melacak history permintaan. Selain itu diperlukan juga sistem yang mengintegrasikan proses pengadaan dengan proses bisnis yang lain seperti gudang, penjualan dan distribusi. Pengembangan sistem terintegrasi yang dimaksud dalam hal ini adalah perlunya suatu sistem ERP khususnya pada modul pengadaan dan pergudangan. Pada penelitian menggunakan standar metodologi ASAP, penelitian hanya sampai pada tahapan realization, meliputi: project management, organizational change management, training, baseline configuration and confirmation, system management, final configuration and confirmation, develop program, final integration test, dan quality check. Hasil yang diperoleh dari penelitian ini yaitu terciptanya integrasi proses bisnis antara pembelian dan gudang sehingga adanya kesesuaian data pada prose permintaan dengan pembelian, Adanya dokumentasi pembelian yang sesuai dengan sistem ERP yang dikembangkan dan Pencarian atau pengecekan data atau proses terkait dengan bagian pembelian dapat dilakukan dengan mudah.
\end{abstract}

Kata Kunci: ERP, SAP, Purchasing, ASAP, Material Management, Procurement

\section{PENDAHULUAN}

Salah satu industri yang bergerak di bidang percetakan batik yang mendesain, memproduksi, dan memasarkan sendiri produk produknya adalah PT. Unggul Jaya Sejahtera. PT Unggul berlokasi di JL. KH. Ahmad Dahlan No. 205 Tirto Pekalongan. Dalam pengelolaan percetakan batik di PT. Unggul terdiri dari sejumlah proses bisnis. Mulai dari pembelian, gudang, penjualan, akuntansi, produksi dan lainlain. Dalam proses bisnis pengadaan terdapat sejumlah aktivitas utama seperti: pengajuan atau permintaan pembelian (purchase request), pembelian barang (purchase order), penerimaan barang (goods receipt), sampai dengan invoice. Saat ini aktivitas pengajuan barang dilakukan dengan membuat dokumen pengajuan perintah pembelian barang dari bagian produksi ke bagian pembelian.

Berdasarkan hasil wawancara dan pengamatan dalam proses pengadaan existing PT Unggul mengalami beberapa masalah. Pada proses pengajuan pembelian (purchase request) data kebutuhan bahan untuk produksi tidak sesuai dengan purchase order yang dibuat oleh divisi purchase. Proses yang berlangsung sering kali menghasilkan dokumen yang tidak sesuai antara permintaan dengan pembelian. Dalam aktivitas pembelian (purchasing) sering kali terjadi perbedaan pencatatan antara barang yang diminta, barang yang dipesan, dan barang yang diterima. Perusahaan juga kesulitan dalam melacak history permintaan.

Permasalahan diatas terjadi karena belum terintegrasinya semua aktivitas dalam proses pengadaan dalam suatu sistem sehingga diperlukan untuk pengembangan sebuah sistem yang mengintegrasikan semua aktivitas dalam proses pengadaan tersebut. Selain itu diperlukan juga sistem yang mengintegrasikan proses pengadaan dengan proses bisnis yang lain seperti gudang, penjualan dan distribusi. Pengembangan sistem terintegrasi yang dimaksud dalam hal ini adalah perlunya suatu sistem ERP khususnya pada modul pengadaan dan pergudangan.

\section{STUDI LITERATUR}

A. $E R P$

Enterprise Resource Planning (ERP) adalah perangkat lunak utama dari perusahaan yang bekerja untuk mengintegrasikan informasi yang ada di semua bidang bisnis yang memiliki tujuan untuk dapat merencanakan dan mengelola semua sumber daya yang tersedia bagi suatu perusahaan sehingga semua bisnis area dalam perusahaan bisa berjalan dengan baik. Sistem ERP juga terdiri dari beberapa modul yang terintegrasi dengan satu sama lain, termasuk manajemen material, penjualan dan distribusi, perencanaan produksi, keuangan, sumber daya manusia, dan lain-lain. Berikut adalah beberapa kriteria yang harus dimiliki oleh sistem informasi perusahaan [1]: 
1. Memiliki empat fungsi dasar yang ada, yaitu:
a. Financial accounting modules
b. Procurement modules
c. Order management modules
d. Inventory management modules

2. Terintegrasi, data tidak berlebihan, menggunakan satu database utama dan menyediakan akses ke semua modul menggunakan single interface.

3. Platform multiuser, bisa diakses oleh lebih dari satu pengguna.

\section{B. Konsep Dasar ERP}

Fungsi bisnis di suatu perusahaan terpisah dan berjalan masingmasing, saat ini dinding pemisah antarfungsi dapat dihilangkan dan dapat diintegrasikan dengan suatu sistem yang disebut ERP. Dengan adanya konsep ERP, antarfungsi dapat saling menggunakan data yang terdapat di perusahaan secara bersamaan. Dengan demikian informasi yang diterima dapat secara langsung diketahui (real time) [2].

\section{SAP}

Pada tahun 1972, lima mantan karyawan IBM - Dietmar Hopp, Hans-Werner Hector, Hasso Plattner, Klaus Tschira, dan Claus Wellenreuther memulai sebuah perusahaan bernama "System Aplication and Product in Data Processing" yang sering dikenal dengan SAP di Mannheim, Jerman [3].

SAP ERP adalah software ERP terkemuka di dunia, yang dikembangkan oleh SAP AG. SAP ERP adalah perangkat lunak yang terintegrasi, memungkinkan informasi untuk dibagi di antara bidang fungsional. Masing-masing departemen fungsional membutuhkan informasi dari departemen lain, yang dibuat mungkin dengan sistem terpadu. Berikut ini adalah komponen dari SAP ERP [4]:

1. SAP ERP Financials Financial Accounting

2. Controlling $(\mathrm{CO})$

3. Human Capital Management (HCM; human resources)

4. Production Planning (PP)

5. Project Systems (PS)

6. Sales and Distribution (SD)

7. Materials Management (MM)

8. Quality Management (QM)

9. Plant Maintenance (PM)

\section{Material Procurement}

Pembelian merupakan suatu investasi dalam hal persediaan dan suatu kelancaran arus bahan kedalam pabrik [5]. Proses pengadaan bahan dimulai dengan pembuatan permintaan pembelian dan berakhir dengan pengolahan pembayaran kepada pemasok. Langkah-langkah procurement dalam SAP adalah sebagai berikut [4]:

1. Create purchase requisition

Membuat permintaan pembelian melalui transaksi ME51N

2. Create $P O$

Membuat PO melalui transaksi ME21N

3. Post the goods receipt
Setelah menerima materi, posting penerimaan barang melalui transaksi MIGO

4. Post the invoice

Setelah menerima faktur dari vendor, mengirim faktur dalam sistem melalui transaksi MIRO.

\section{METODE PENELITIAN}

\section{A. Model Konseptual}

Berdasarkan model konseptual pada Gambar 1 dalam pengembangan sistem informasi berbasis ERP didasari oleh permasalahan yang terdapat pada pengadaan PT Unggul dimana terdapat kebutuhan pencatatan antara barang yang diminta, barang yang dipesan dan barang yang diterima. Selain itu, data kebutuhan bahan untuk produksi tidak sesuai dengan purchase order yang dibuat oleh bagian purchase. Dalam proses pengembangan modul purchasing pelaku yang terlibat dalam lingkungan tersebut adalah bagian pembelian di perusahaan dan pimpinan yang menyetujui pembelian. Pengembangan menggunakan teknologi SAP ERP menggunakan modul purchasing. Penelitian menggunakan konsep pengembangan sistem informasi berbasis Enterprise Resource Planning, Change Management, Project Management, dan Business Blueprint. Dalam memperkuat konsep menggunakan metode ASAP, melakukan wawancara kepada bagian pembelian untuk mengetahui proses bisnis eksisting pada bagian pembelian, selain itu observasi juga dilakukan. Penelitan akan menghasilkan sebuah sistem informasi untuk bagian pembelian di PT Unggul menggunakan SAP. Sistem SAP tersebut akan melewati fase evaluasi menggunakan skenario final integration testing.

\section{B. Sistematika Penelitian}

ASAP (Accelerated SAP) adalah sebuah metodologi yang direkomendasikan oleh perusahaan SAP untuk implementasi software ERP yang dirancang berdasarkan pengalaman dalam membuat dan mengimplementasikan SAP ERP dalam berbagai jenis perusahaan di dunia dan terdiri dari sejumlah template, pertanyaan dan skenario yang membutuhkan input pengguna untuk membantu pengguna menentukan cara terbaik untuk mengimplementasikan implementasi SAP [6].

Standar metodologi ASAP memberdayakan perusahaan untuk menggunakan fitur yang berkembang dan peralatan yang telah dibangun pada solusi SAP. Standar metodologi ASAP memiliki tahapan terstruktur sebagai berikut [7]:

1. Project Preparation

Selama fase ini team berjalan melalui perencanaan awal dan persiapan proyek SAP.

2. Business Blueprint

Tujuan dari tahap ini adalah untuk mencapai pemahaman bersama tentang bagaimana perusahaan bermaksud untuk menjalankan SAP untuk mendukung bisnis mereka. Dalam standar metodologi ASAP hasilnya adalah Blueprint Bisnis, dokumentasi rinci dari hasil yang dikumpulkan selama lokakarya persyaratan. 


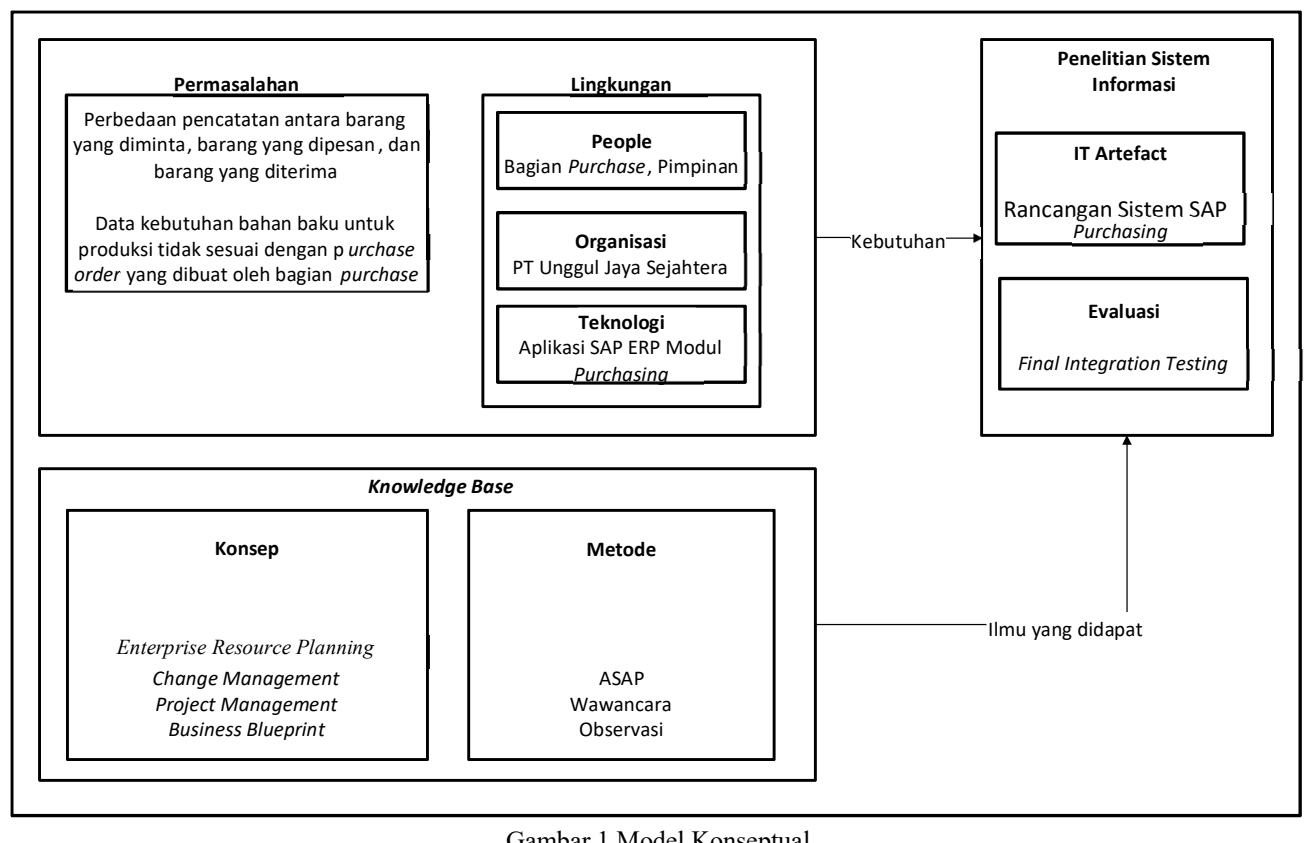

Gambar 1 Model Konseptual

\section{Realization}

Tujuan dari fase ini adalah untuk menerapkan semua persyaratan proses bisnis berdasarkan Blueprint. Sistem konfigurasi standar metodologi ASAP dilakukan dalam dua paket: konfigurasi dasar (lingkup utama) dan konfigurasi akhir (sisa lingkup). Selama fase ini solusinya juga diuji.

4. Final Preparation

Tujuan dari fase ini adalah untuk menyelesaikan persiapan akhir (termasuk pengujian teknis, akhir pelatihan pengguna, manajemen sistem dan kegiatan migrasi) untuk menyelesaikan kesiapan. Tahap Final Preparation juga berfungsi untuk menyelesaikan semua masalah terbuka secara kritis.

5. Go-Live Support

Tujuan dari fase ini adalah untuk bergerak dari lingkungan yang pra-produksi berorientasi proyek untuk operasi produksi dapat berjalan.

Dalam penelitian menggunakan metode ASAP yang memiliki tahapan berikut: project preparation, blueprint, realization, final preparation dan go-live. Penelitian ini dilakukan hingga tahapan realization.

\section{HASIL DAN ANALISIS}

\section{A. Organizational Structure Definition}

Definisi struktur organisasi SAP berdasarkan proses bisnis organisasi perusahaan. Struktur ini berdampak signifikan pada prosedur dimana SAP dikonfigurasi untuk memenuhi kebutuhan perusahaan. Gambar 2 merupakan pemetaan struktur bisnis dalam perusahaan.

\section{B. Baseline Configuration and Confirmation}

Konfigurasi terbagi menjadi dua bagian yaitu konfigurasi dasar dan konfigurasi akhir. Tahap ini berkaitan dengan konfigurasi dan konfirmasi pengaturan untuk lingkup baseline. Lingkup baseline mencakup skenario, proses, dan fungsi yang merupakan persyaratan prioritas perusahaan.

ASAP merekomendasikan agar perusahaan pada awalnya mempertimbangkan proses untuk konfigurasi dasar yang dapat dikonfigurasi tanpa memodifikasi sistem. Konfigurasi SAP dilakukan dengan bantuan implementation guide (IMG). Konfigurasi digunakan untuk menambahkan kolom, mengubah field dan mengubah daftar dropdown untuk menyesuaikan dengan fungsi organisasi. IMG adalah di mana kita menentukan struktur perusahaan dan pengaturan lainnya yang diperlukan untuk fungsi SAP sesuai dengan persyaratan organisasi.

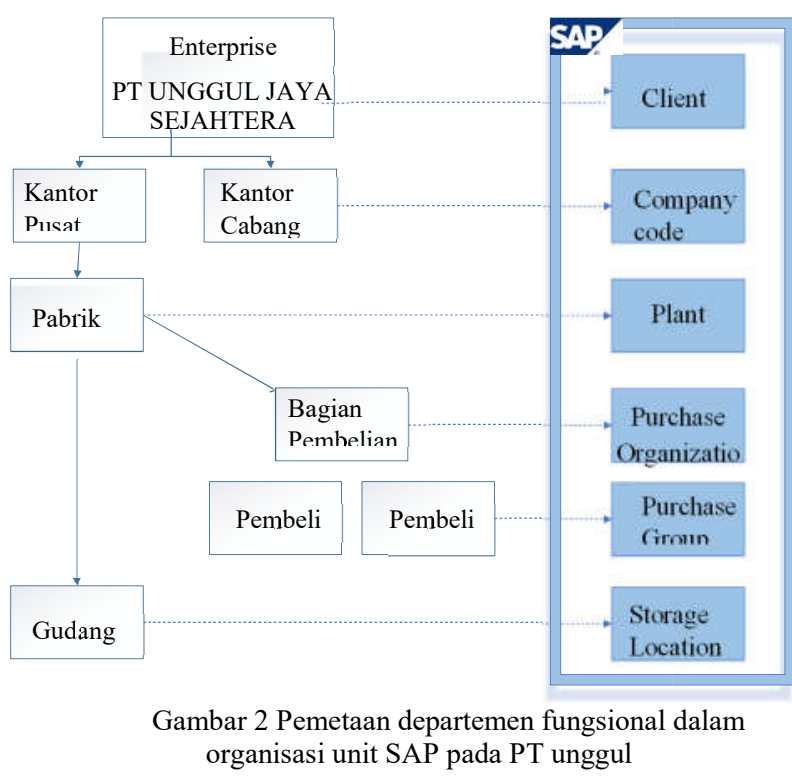

C. Business Process Analysis

Pada PT Unggul pengadaan eksisting yaitu pengadaan stock. Stok bahan adalah bahan yang disimpan dalam stok 
gudang di perusahaan. Bahan-bahan ini disimpan dalam stok setelah diterima dari vendor. Stok bahan ini terus meningkat atau menurun berdasarkan jumlah kuantitas yang diterima atau dikeluarkan. Perusahaan perlu mendapatkan kain mori, obat atau pewarna yang digunakan selama produksi. Bahan ini adalah contoh dari bahan stok, bahan langsung dibeli, disimpan dalam persediaan, dan dikeluarkan ke departemen produksi berdasarkan kebutuhan. Kegiatan pengadaan stock di PT Unggul.

Proses dimulai dengan bagian pembelian membuat form order pembelian dan diverifikasi oleh pimpinan. Selanjutnya form order pembelian dikirim ke pemasok, barang yang dipesan segera dikirimkan ke gudang bersamaan dengan surat jalan. Untuk faktur pembelian dikirim ke bagian pembelian sebagai tagihan. Proses terakhir yaitu bagian pembelian membuat laporan pembelian.

\section{Business Process Definition}

Pada Gambar 3 menjelaskan bagaimana rangkaian kegiatan yang ada didalam proses rancangan pengadaan stok. Proses pengadaan bahan stok adalah sebagai berikut:

\section{a. Order Pembelian}

Membuat order pembelian melalui transaksi ME21N, dengan mengacu pada permintaan pembelian. Jika sumber tidak ditetapkan dalam permintaan pembelian, masukkan vendor dan harga.

\section{b. Bukti Penerimaan Barang}

Setelah menerima barang, posting penerimaan barang melalui transaksi MIGO, dengan mengacu PO atau order pembelian. Semua rincian dalam bukti penerimaan barang disalin dari PO.

c. Posting faktur

Setelah menerima faktur, bagian pembelian mengirim faktur di sistem melalui transaksi MIRO. Masukkan tanggal dokumen, posting tanggal, dan nomor PO.

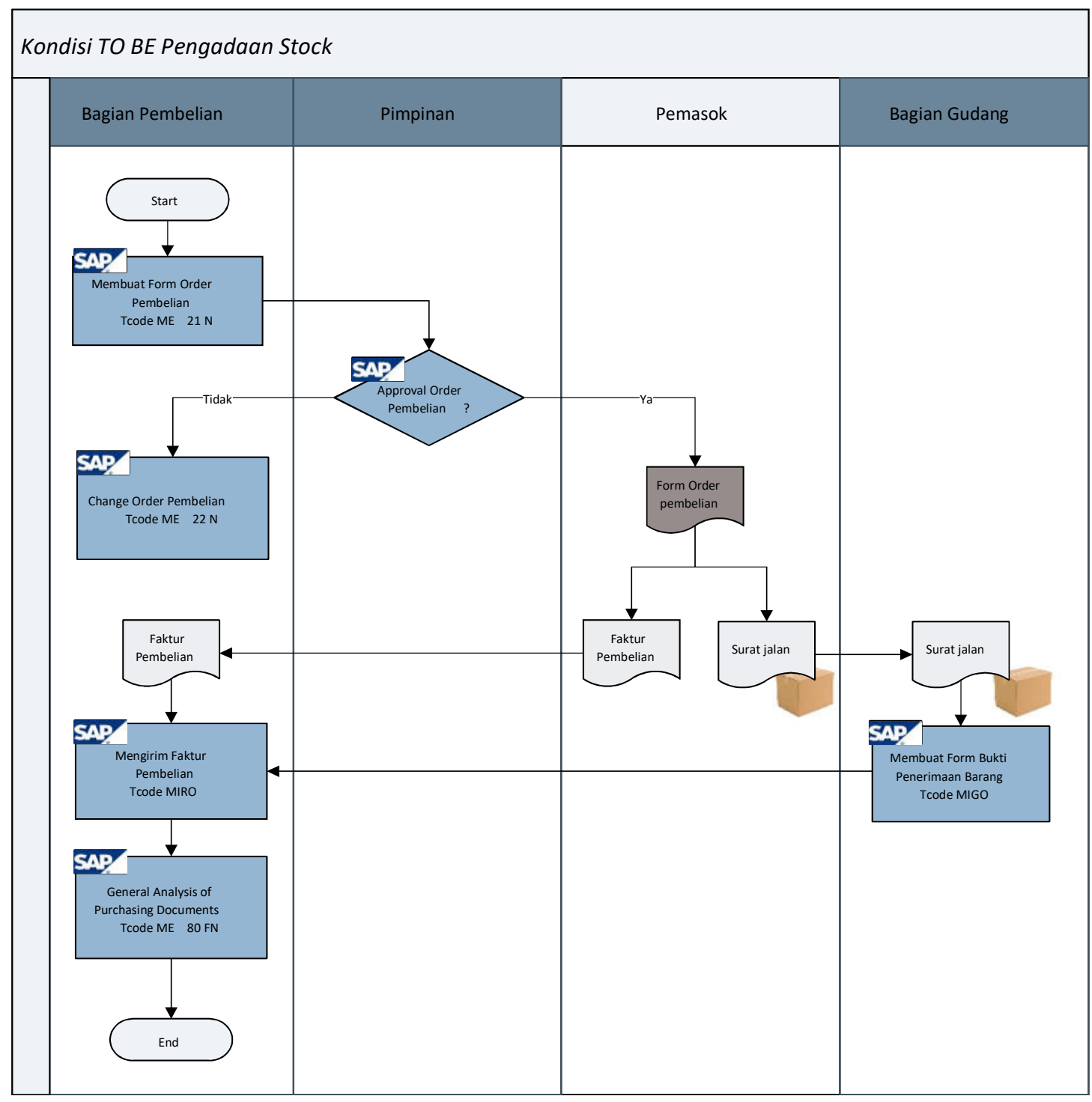

Gambar 3 Proses bisnis rancangan pengadaan stok 


\section{E. Analisis GAP dan FIT}

Analisis fit-gap untuk menganalisis kesesuaian dan kesenjangan antara sistem SAP dengan proses bisnis yang berjalan [8]. Perbedaan atau kesenjangan tersebut membantu merencanakan langkah-langkah yang dilakukan. Tabel analisis gap dan fit dapat dilihat pada Lampiran 1.

\section{KESIMPULAN}

Pengembangan aplikasi SAP modul purchase dilakukan berdasarkan analisis dari kebutuhan perusahaan dan analisis proses bisnis SAP menggunakan metode ASAP. Metode ASAP digunakan karena memungkinkan peneliti untuk berinteraksi dengan stakeholder PT Unggul jaya dan melakukan proses rancangan secara terus menerus sehingga kebutuhan dari perusahan lebih cepat terpenuhi

Sudah dihasilkan sistem yang terintegrasi pada proses pengadaan. Adanya sistem database yang terpusat memberikan kemudahaan kepada perusahaan untuk melihat data hasil pembelian yang telah dilakukan sebelumnya sehingga proses pembelian atau history pembelian terdokumentasi dan tersimpan dengan baik.

Aplikasi SAP modul purchasing dapat terintegrasi dengan bagian lain yang terkait terhadap proses material management. Bentuk integrasi yang terjadi yaitu dengan bagian warehouse terintegrasi terkait pemberian informasi mengenai pengadaan, penerimaan dan pengeluaran bahan

\section{DAFTAR PUSTAKA}

[1] Marolop, Victor, Ari Yanuar Ridwan, dan R. Wahjoe Witjaksono. Pengembangan Sistem ERP Berbasis Adempiere Untuk Modul Procurement Dengan Metodologi ASAP Pada Perum Bulog Divisi Regional Jabar. (2016)

[2] Rokhmaningsih, Zenita, Ari Yanuar Ridwan, and R. Wahjoe Witjaksono. "Perancangan Sistem Fixed Asset Management Berbasis Openerp Dengan Metode Soft System Methodology (Studi Kasus: Rsud Al Ihsan) Designing Fixed Asset Management System Based On Openerp Using Soft System Methodology." (2015)

[3] Damayanti, Felicia Maria Cynthia. "Evaluasi dan Rencana Pengembangan Penerapan Aplikasi Enterprise Resource Planning (ERP): Studi Kasus pada PT Astra Graphia." ComTech: Computer, Mathematics and Engineering Applications 2.2 (2011): 912-922.

[4] Agrawal, Akash. 2012. Customizing Materials Management Processes in SAP ${ }^{\circledR}$ ERP. Boston (MA): Galileo Press. ISBN 978-1-59229-821-1

[5] Hidayat, Afrizal Samsul, RD Rohmat Saedudin, and R. Wahjoe Witjaksono. "Perancangan Sistem ERP Dengan Modul Purchasing Dan Inventory Berbasis Odoo 9 Dengan Metode Asap Pada PT. Aretha Nusantara Farm." (2016)

[6] M. Lutovac, "The Successful Methodology for Enterprise Resource Planning (ERP) Implementation," Journal of Modern Accounting and Auditing, vol. VIII, no. 12, pp. 1838-1847, 2012.
[7] Saravanan, \& Sundar. (2014). Analysis of ERP Implementations. International Journal of Research in Business Management, 2(5), 69.

[8] EKAWATI, Evy. Strategi Perencanaan Pengembangan Sistem SAP Pada Human Capital and Legal di Institusi Pendidikan XYZ. Jurnal ComTech, 2014, 5.01.

\section{LAMPIRAN}

Lampiran 1 Analisis proses bisnis gap dan fit 
Tabel di bawah ini adalah analisis gap yang menunjukkan kesenjangan antara bisnis proses yang terdapat pada PT. Unggul dan proses di SAP. Keterangan:

$\mathrm{N} \quad$ : Tidak, berarti kebutuhan tidak terpenuhi

P : Sebagian, berarti kebutuhan tidak sepenuhnya terpenuhi

F : Terpenuhi, berarti kebutuhan sepenuhnya terpenuhi

\section{LAMPIRAN 1 ANALISIS PROSES BISNIS GAP DAN FIT}

\begin{tabular}{|c|c|c|c|c|c|c|c|}
\hline \multirow{2}{*}{ No } & \multirow{2}{*}{ Bisnis Proses Eksisting } & \multirow{2}{*}{ Kebutuhan } & \multicolumn{3}{|c|}{ Pemenuhan } & \multirow{2}{*}{ Informasi } & \multirow{2}{*}{ Solusi } \\
\hline & & & $\mathbf{N}$ & $\mathbf{P}$ & $\mathbf{F}$ & & \\
\hline \multirow{4}{*}{1} & \multirow{4}{*}{$\begin{array}{l}\text { Proses Penawaran dan Pemilihan } \\
\text { pemasok yang digunakan bagian } \\
\text { pembelian untuk } \\
\text { mengidentifikasi pemasok. }\end{array}$} & \multirow{4}{*}{$\begin{array}{l}\text { Perlu sistem untuk mencatat } \\
\text { setiap pemasok dan penawaran } \\
\text { sehingga seleksi pemasok dan } \\
\text { penawaran dapat dibuat secara } \\
\text { otomatis dengan mengacu pada } \\
\text { permintaan pembelian melalui } \\
\text { transaksi }\end{array}$} & & & & Eksisting: & \multirow{4}{*}{$\begin{array}{l}\text { Pencatatan data pemasok disimpan dan } \\
\text { menjadi riwayat pemasok dalam sistem untuk } \\
\text { seleksi pemasok, data digunakan untuk } \\
\text { membandingkan penawaran bahan baku } \\
\text { sesuai kebutuhan }\end{array}$} \\
\hline & & & & & $y$ & $\begin{array}{l}\text { Penawaran dibuat secara manual, dan } \\
\text { pengechekan pemasok berdasarkan dokumen } \\
\text { kontrak dan riwayat pembelian }\end{array}$ & \\
\hline & & & & & 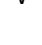 & SAP: & \\
\hline & & & & & & $\begin{array}{l}\text { Di SAP dapat membuat penawaran secara } \\
\text { otomatis dari permintaan pembelian dan dapat } \\
\text { menyeleksi pemasok }\end{array}$ & \\
\hline \multirow{4}{*}{2} & \multirow{4}{*}{$\begin{array}{l}\text { Pembuatan Kontrak dengan } \\
\text { pemasok }\end{array}$} & \multirow{4}{*}{$\begin{array}{l}\text { Perlu sistem untuk membuat } \\
\text { kontrak dan penjadwalan untuk } \\
\text { penerimaan bahan }\end{array}$} & & & \multirow{4}{*}{$v$} & Eksisting: & \multirow{4}{*}{$\begin{array}{l}\text { Membuat kontrak dan penjadwalan } \\
\text { pengiriman dapat dilakukan di sistem SAP }\end{array}$} \\
\hline & & & & & & $\begin{array}{l}\text { Pemimpin membuat penawaran perjanjian } \\
\text { dengan pemasok untuk membuat kontrak } \\
\text { selama periode terntentu dan menentukan } \\
\text { jadwal dalam surat kontrak }\end{array}$ & \\
\hline & & & & & & SAP: & \\
\hline & & & & & & $\begin{array}{l}\text { SAP menyediakan fitur untuk merekam kontrak } \\
\text { dengan pemasok dan terdapat penjadwalan } \\
\text { bahan yang harus dikirim sesuai dengan kontrak. }\end{array}$ & \\
\hline \multirow{4}{*}{3} & \multirow{4}{*}{ Proses Order Pembelian } & \multirow{4}{*}{$\begin{array}{l}\text { Perlu sistem untuk membuat } \\
\text { form order pembelian dan form } \\
\text { dapat digunakan untuk referensi } \\
\text { laporan pembelian berdasarkan } \\
\text { pemasok maupun bahan }\end{array}$} & & & \multirow{4}{*}{$\checkmark$} & Eksisting: & \multirow{4}{*}{$\begin{array}{l}\text { Membuat PO di SAP dengan mengacu pada } \\
\text { permintaan pembelian. }\end{array}$} \\
\hline & & & & & & $\begin{array}{l}\text { Staff pembelian membuat form order pembelian } \\
\text { menggunakan Microsoft Excel sesuai dengan } \\
\text { template yang ditetapkan oleh PT Unggul. }\end{array}$ & \\
\hline & & & & & & SAP: & \\
\hline & & & & & & $\begin{array}{l}\text { SAP menyediakan fitur untuk mencatat, mengirim } \\
\text { dan menyimpan form order pembelian }\end{array}$ & \\
\hline \multirow{4}{*}{4} & \multirow{4}{*}{ Penerimaan Barang } & \multirow{4}{*}{$\begin{array}{l}\text { Perlu sistem untuk merekam } \\
\text { setiap bahan yang PT Unggul } \\
\text { terima. Dan melakukan } \\
\text { pemeriksaan kualitas di gudang. }\end{array}$} & & \multirow{4}{*}{ v } & & Eksisting: & \multirow{4}{*}{$\begin{array}{l}\text { Pengecekan kualitas dilakukan secara manual } \\
\text { oleh pekerja dan setiap bahan yang diterima } \\
\text { dan tidak diterima, menjadi catatan dalam } \\
\text { SAP. }\end{array}$} \\
\hline & & & & & & $\begin{array}{l}\text { Ada pemeriksaan kualitas untuk setiap bahan } \\
\text { sebelum diterima. Dan kemudian materi yang } \\
\text { diterima dan tidak diterima disimpan dalam } \\
\text { bentuk form bukti penerimaan barang. }\end{array}$ & \\
\hline & & & & & & SAP: & \\
\hline & & & & & & $\begin{array}{l}\text { Di SAP pengecekan kualitas menggunakan modul } \\
\text { yang berbeda. Tapi SAP bisa merekam materi } \\
\text { yang diterima dan tidak diterima. }\end{array}$ & \\
\hline
\end{tabular}




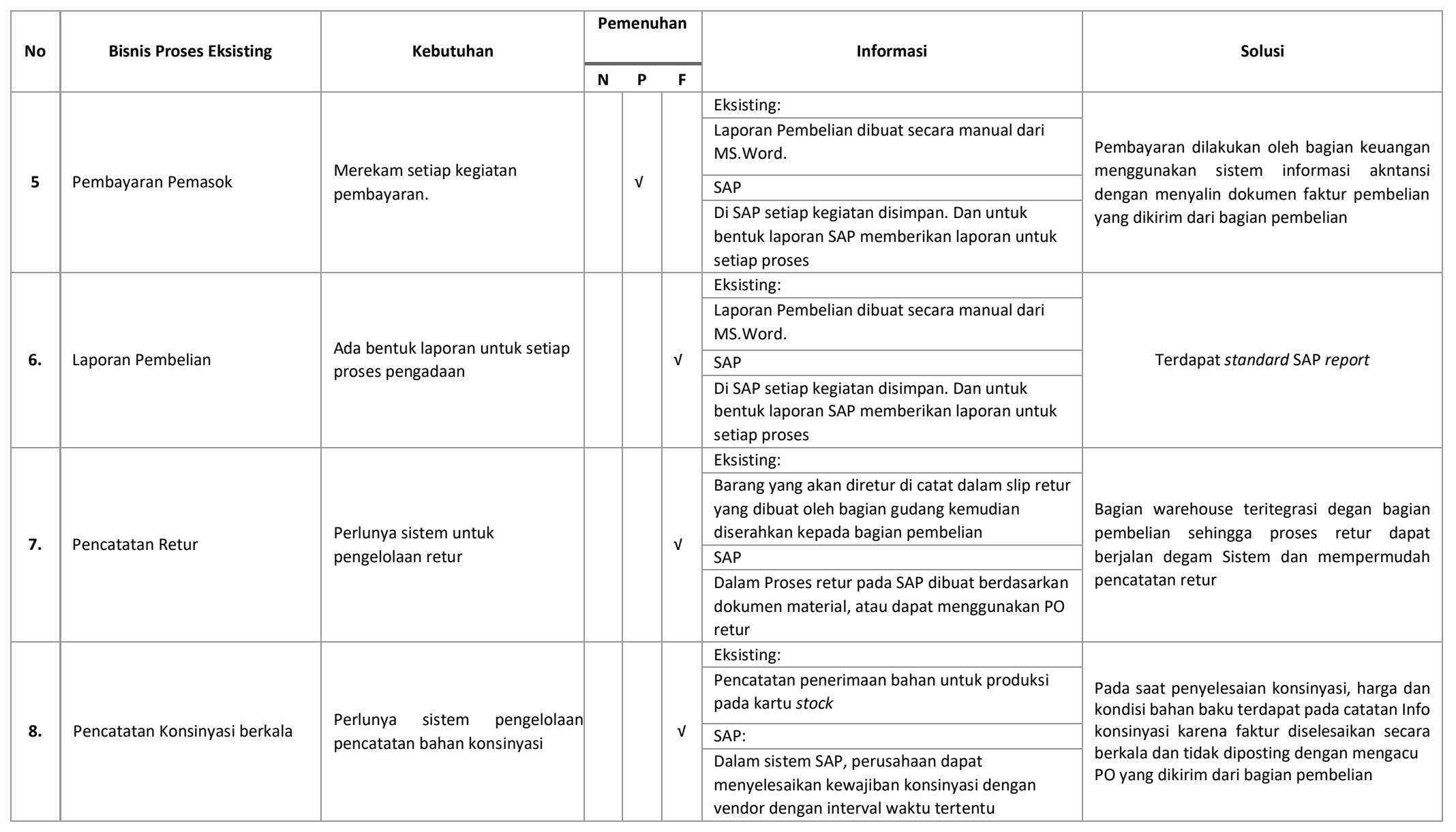

